Kumawula, Vol. 1, No.2, Agustus 2018, Hal 75 - 89

DOI:http://10.24198/kumawula.v1i2.19612

ISSN 2620-844X (online)

Tersedia online di http://jurnal.unpad.ac.id/kumawula/index

\title{
PENCEGAHAN RADIKALISASI MELALUI PENGEMBANGAN DEMOKRASI ISLAMIK DI KECAMATAN TEMPURAN KABUPATEN KARAWANG
}

\author{
PREVENTION OF RADICALISATION THROUGH DEVELOPMENT OF \\ ISLAMIC DEMOCRACY \\ IN SUBDISTRICT OF TEMPURAN, REGENCY OF KARAWANG
}

\author{
Windy Dermawan ${ }^{1 *}$, RMT Nurhasan Affandi ${ }^{2}$, Gilang Nur Alam ${ }^{3}$ \\ 1, 2, ${ }^{3}$ Dosen pada Departemen Hubungan Internasional Universitas Padjadjaran \\ *windy.dermawan@unpad.ac.id
}

\begin{abstract}
The community development activity (PPM) aims to build an inclusive society, increase tolerance and prevent radicalism in Subdistrict of Tempuran, Regency of Karawang. Achieving this goal, we introduce democratic values based on Western political philosophy and Islam and explore participants' understanding of radicalism. We engage participants to observe local values in the community at the location of the activity and then explore this relevance to Islamic values. The methods of PPM use the Problem Based Learning and Community Based Research (CBR) in the formulation of an idea that suits the needs of the community in solving the problem. The PPM concluded that there is an increase in scores of knowledge before and after training by 21\%, which is the most participants understood Islamic democracy as an inherent part of social life. There is also an increase in participants' awareness in preventing radicalism by $28 \%$, which is the most participants realize the importance of preventing radicalism through the development of an inclusive life, the spirit of multiculturalism and tolerance in social plurality. Thus, the PPM concludes that there is an increase in participants' knowledge and awareness in the implementation of Islamic democratic values and the prevention of radicalism through socialization and training.
\end{abstract}

Keywords: Socialization, Islamic democracy, radicalism, prevention.

\begin{abstract}
ABSTRAK
Kegiatan pengabdian pada masyarakat (PPM) ini bertujuan untuk membentuk masyarakat yang inklusif, meningkatkan toleransi dan mencegah radikalisasi di Kecamatan Tempuran Kabupaten Karawang. Untuk mencapai tujuan tersebut, kami mengenalkan nilai-nilai demokrasi berdasarkan filsafat politik Barat maupun Islam dan menggali pemahaman peserta mengenai radikalisme di Kecamatan Tempuran Kabupaten Karawang. Kami mengajak kepada peserta untuk mengamati nilai-nilai lokal (local wisdom) dalam masyarakat di lokasi kegiatan kemudian menggali relevansinya dengan nilai-nilai islamik. Kegiatan PPM ini menggunakan metode Problem Based Learning dan Community Based Research (CBR) di dalam perumusan suatu gagasan yang sesuai dengan kebutuhan masyarakat di dalam memecahkan permasalahannya. PPM ini menyimpulkan bahwa terdapat peningkatan skor pengetahuan sebelum dan setelah pelatihan sebesar 21\%, dimana sebagian besar peserta memahami demokrasi islamik sebagai bagian yang inheren dalam kehidupan bermasyarakat. Terdapat pula peningkatan kesadaran peserta di dalam pencegahan radikalisasi sebesar $28 \%$, dimana sebagian besar peserta menyadari pentingnya pencegahan radikalisasi melalui pembangunan kehidupan yang inklusif,
\end{abstract}


semangat multikulturalisme dan toleransi terhadap pluralitas sosial. Dengan demikian, PPM ini menyimpulkan bahwa terdapat peningkatan pengetahuan dan kesadaran peserta dalam pengamalan nilai-nilai demokrasi islamik dan pencegahan radikalisasi melalui sosialisasi dan pelatihan.

Kata kunci: sosialisasi, demokrasi islamik, radikalisasi, pencegahan.

\section{PENDAHULUAN}

Fenomena radikalisme ${ }^{1}$ menjadi isu sosial dan politik saat ini, terlebih isu ini semakin mencuat pasca 11 September 2001 dengan terjadinya tragedi penyerangan terorisme yang dilakukan oleh Al-Qaeda ${ }^{2}$ kepada beberapa objek vital Amerika Serikat. Bahkan, Al-Qaeda mengklaim telah menyebarkan doktrin salafi jihadisme di beberapa negara di Asia Tenggara (Baylis, 2008). Kehadiran jaringan Al-Qaeda di Asia Tenggara ditandai dengan munculnya beberapa kelompok islam radikal dan berdirinya Jamaah Islamiyah (JI) di Indonesia. Tujuan dari JI ini adalah membentuk Daulah Islamiyah (negara Islam) di tingkat nasional, kemudian diikuti oleh pembentukan kekhalifahan regional, dan global (Fealy, 2004).

Penyebaran radikalisme menjadi semakin massif seiring dengan perkembangan teknologi siber yang dijadikan sarana bagi pihak tertentu melebarkan pengaruhnya melalui dunia maya (Cahill, 2012). Kelompok radikal memahami bahwa melalui media sosial, mereka dapat melakukan perekrutan anggota baru calon jihadis dimana bahwa Facebook, Youtube, Whatsapp, Line, Telegram berpotensi sebagai alat efektif di dalam memperluas ideologi dan rekruitmen anggota baru (Golose, 2008). Gunaratna (2002) mengatakan bahwa Al-Qaeda memanfaatkan internet untuk memperluas pengaruhnya di Asia Tenggara. Aksi terorisme di Indonesia semakin marak terjadi pasca Orde Baru, diantaranya aksi terorisme terhadap sejumlah gereja (2000), Bom Bali 1 (2002), Bom Bali 2 (2005), Kedutaan Besar Australia di Indonesia (2004), serangan teror terhadap Hotel J.W. Marriot (2003 dan 2009) (Heiduk, 2012), hingga terakhir serangan teror di Jawa Timur.

Salah satu provinsi di Indonesia yang rentan terhadap penyebaran radikalisasi ${ }^{3}$ yaitu Jawa Barat. Data Lazuardi Birru menyimpulkan bahwa Jawa Barat menjadi wadah bagi

\footnotetext{
1 Istilah radikalisme berdasarkan Kamus Besar Bahasa Indonesia (KBBI) berarti (1) paham atau aliran radikal dalam politik; (2) paham atau aliran yang menginginkan perubahan atau pembaharuan sosial dan politik dengan cara kekerasan atau drastis; (3) sikap ekstrem dalam aliran politik (Pusat Bahasa Depdiknas RI, 2008: 1151). Radikalisme di Indonesia dapat dianalisis berdasarkan dua pendekatan, yaitu pendekatan berorientasi keamanan yang menganalisis radikalisme sebagai isu terorisme dan kekerasan, yang kedua yaitu pendekatan berorientasi strukturalis, yang menganalisis radikalisme di Indonesia berakar pada masalah kemiskinan, ketimpangan dan marginalisasi dalam aspek ekonomi dan sosial yang tumbuh subur di masyarakat (Jati, 2013).

${ }^{2}$ Organisasi milisi muslim yang berpusat di Afghanistan yang dipimpin oleh Osama bin Laden dan mengklaim telah memiliki jaringan di lebih dari 50 negara.

${ }^{3}$ terminologi radikalisasi dalam tulisan ini merujuk pada proses mengubah sikap seseorang atau sekelompok orang yang tergolong menganut radikalisme ke arah tindakan melakukan kekerasan dengan menimbulkan kerusakan massif terhadap
} 
radikalisme tertinggi Nangroe Aceh Darussalam. Kerentanan terhadap radikalisme di Jawa Barat disebabkan oleh: paham jihad, alienasi dan deprivasi, tindakan intoleransi, posisi yang terancam, merasa tidak aman, agenda islamisme dan keanggotaan radikal ("Jawa Barat Kantong Radikalisme Tertinggi,” 2011). Dari aspek sejarah, gerakan islam politik di Jawa Barat pun sempat diisi oleh kelompok revolusioner dengan nama Darul Islam/Tentara Islam Indonesia (DI/TII) yang pusat operasinya di Jawa Barat dengan pimpinannya yaitu S.M. Katosuwiryo. Gerakan ini menyebar ke Sulawesi Selatan dan Aceh di bawah kepemimpinan Kahar Muzakar dan Daud Beureuh dari mulai tahun 1940 hingga pertengahan tahun 1960an (Lim, 2005; Umam, 2006) dan memiliki tujuan menerapkan syariat Islam yang terlepas dari Pemerintah Indonesia (Van Bruinessen, 2002).

Salah satu sasaran radikalisasi yaitu pada remaja yang duduk di sekolah menengah pertama hingga atas, bahkan tidak jarang yang menjadi pendukung gerakan radikalisme telah masuk ke kalangan mahasiswa. Hal ini dikarenakan secara psikologis, pelajar SMA dan Mahasiswa merupakan golongan usia yang berada pada masa pencarian identitas diri sehingga rentang terhadap ajaran intoleransi dan radikalisme, apalagi posisi mereka berikutnya akan menjadi tenaga kerja di berbagai sektor kehidupan, baik negara maupun swasta. Fenomena ini semakin kompleks manakala di era globalisasi ini penggunaan internet menjadi bagian dari kebutuhan individu sehingga berkembangnya celah radikalisasi secara individu melalui efek propaganda dan menyesuaikan dengan permintaan kelompok sasaran (Koehler, 2014).

Beberapa hasil survai telah membuktikan hal tersebut, diantaranya yaitu survai dari Lembaga Islam dan Perdamaian (LaKIP) pada 2010, dinyatakan bahwa 48,9\% responden yang terdiri dari para siswa di Jabodetabek menyatakan setuju terhadap aksi radikal (Lestari, 2016). Hal ini menjadi perhatian para pendidik agar mengantisipasi faham ini. Meskipun hanya berupa persetujuan, jika dibiarkan maka akan mengarah pada perubahan kepribadian yang cenderung melakukan kekerasan untuk mencapai tujuan. Hasil survai lain yang dilakukan di Bandung dan Jakarta, menyatakan bahwa 2,4\% siswa terindikasi intoleran aktif dan radikal. Alvara Research Center melaporkan hasil survai nya terhadap 1.800 mahasiswa dan 2.400 pelajar di seluruh Pulau Jawa dan kota besar di Indonesia, yaitu bahwa radikalisme sudah masuk kalangan pelajar dan mahasiswa.

Hasil survai dari Pusat Pengkajian Islam dan Masyarakat (PPIM) UIN Syarif Hidayatullah Jakarta menyatakan bahwa intoleransi dan radikalisasi telah memberikan

fasilitas publik dan atau menjatuhkan korban jiwa. 
pengaruh terhadap banyak sekolah dan universitas di Indonesia. Hasil survei terbaru Pusat Pengkajian Islam dan Masyarakat (PPIM) UIN Syarif Hidayatullah Jakarta menunjukkan pengaruh intoleransi dan radikalisasi menjalar ke banyak sekolah dan universitas di Indonesia. Terdapat 51,1\% responden muslim yang memiliki pemikiran intoleran terhadap kelompok minoritas, seperti Ahmadiyah dan Syiah, dan sebanyak 34,3\% responden memiliki pemikiran intoleran terhadap kelompok agama di luar Islam. Survai pun pernah dilakukan oleh Badan Nasional Penanggulangan Terorisme (BNPT) terhadap 15 provinsi di Indonesia, dimana disimpulkan bahwa 39\% mahasiswa tertarik pada ajaran radikal. Berbagai hasil survai di atas menunjukkan bahwa generasi muda menjadi target dari penyebaran paham radikal, termasuk kampus menjadi tempat yang rentan dari penyebaran paham tersebut. Bahkan, berdasarkan kajian Afrianty (2012), lembaga pendidikan tinggi islam di Indonesia telah menjadi lahan subur bagi para ekstremis agama. Hal ini didukung oleh perubahan dalam kurikulum di universitas islam negeri telah memberi kemungkinan perkembangan pemahaman Islam yang lebih konservatif atau radikal masuk dalam kehidupan kampus.

Hasil survai di atas menunjukkan bahwa potensi radikalisasi di kalangan remaja dapat dikatakan minoritas dan sangat jauh bila dibandingkan dengan mayoritas muslim moderat di Indonesia, namun nilai minoritas tersebut, menurut Lindsey (2011), aktivis garis keras akan terus menghantui demokrasi di Indonesia. Kelompok-kelompok radikal tersebut akan melanjutkan upaya mereka untuk meraih tujuan mereka dalam menegakkan dan mempromosikan ideologi mereka baik melalui mekanisme demokratis maupun tindak kekerasan. Pergerakan radikalisme agama merupakan pemicu munculnya terorisme yang berbahaya sehingga memerlukan pencegahan dan penanganan yang komprehensif (Widyaningsih, Sumiyem, \& Kuntarto, 2017). Oleh karena itu, sebagai upaya mencegah radikalisme di Provinsi Jawa Barat, kami berupaya melaksanakan sosialisasi dengan memfokuskan pada para siswa di Kecamatan Tempuran Kabupaten Karawang.

Berdasarkan analisis permasalahan yang ada di wilayah kegiatan, diketahui bahwa penduduk di Kecamatan Tempuran Kabupaten Karawang masih terbatas dalam hal pengetahuan tentang pencegahan radikalisasi. Sejalan dengan hal tersebut, pemasalahan dapat diuraikan berikut ini.

1. Para perangkat desa Pancakarya masih terbatas pengetahuan mengenai radikalisasi dan upaya pencegahannya;

2. Para orang tua siswa di Kecamatan Tempuran belum memiliki pemahaman utuh mengenai radikalisasi dan upaya pencegahannya; 
3. Pencegahan radikalisasi melalui upaya preventif dan humanis dan sejalan dengan kaidah-kaidah atau nilai-nilai relijik masih minim diwacanakan, khususnya di kalangan pelajar di Kecamatan Tempuran;

4. Arus media informasi dan komunikasi yang berkembang dan adaptasi penduduk terhadap perkembangan penggunaan teknologi memberikan efek pada rentannya radikalisasi di Kabupaten Karawang, khususnya para pelajar yang telah mengenal penggunaan gajet sebagai produk teknologi.

Berdasarkan uraian tersebut, tim Pengabdian Pada Masyarakat (PPM) Departemen Hubungan Internasional Universitas Padjadjaran turut serta berperan aktif sebagai upaya merespon permasalahan tersebut melalui pelaksanaan Sosialisasi Pencegahan Radikalisasi melalui Pengembangan Demokrasi Islamik di Kecamatan Tempuran Kabupaten Karawang, dengan studi kasus terhadap para siswa di SMAN 1 Tempuran, Kabupaten Karawang. Tujuan dilaksanakannya kegiatan ini yaitu meningkatkan pemahaman para siswa mengenai radikalisasi dan membekali mereka dengan upaya pencegahannya cara-cara yang demokratis dan islamik.

\section{METODE}

PPM ini menggunakan metode Problem Based Learning dan Community Based Research (CBR) di dalam perumusan suatu gagasan yang sesuai dengan kebutuhan masyarakat di dalam memecahkan permasalahannya. CBR ini merupakan suatu model penelitian yang melibatkan masyarakat atas dasar komitmen mereka untuk memberikan dukungan sumberdaya dan keterlibatan dalam proses penelitian dalam upaya menghasilkan produk yang bermanfaat bagi para pihak yang terlibat (peneliti maupun masyarakat) (Banks \& Manners, 2012).

PPM ini merupakan suatu bentuk upaya peneliti di dalam membentuk masyarakat yang inklusif, meningkatkan toleransi dan mencegah radikalisasi di Kecamatan Tempuran Kabupaten Karawang. PPM menjadi sarana bagi peneliti untuk memberdayakan masyarakat berdasarkan prinsip research based community services melalui peran aktif komunitas/institusi (pendidik, organisasi masyarakat, organisasi kepemudaan, tokoh masyarakat) di dalam peningkatan kewaspadaan dan penumbuhan kesadaran masyarakat terhadap pengembangan demokrasi islamik sebagai upaya mencegah radikalisasi di Kecamatan Tempuran Kabupaten Karawang.

Tahapan kegiatan dalam PPM ini terbagi menjadi dua, diantaranya sosialisasi kegiatan dan focus group discussion dengan berbasiskan pada problem based learning dan pendampingan dalam perumusan gagasan melalui metode CBR. Sasaran yang terlibat dari kegiatan ini terdiri dari unsur orang tua siswa, para siswa di SMAN 1 Tempuran, perangkat 
desa Pancakarya, tokoh masyarakat, tokoh pemuda dan tokoh organisasi massa di Kecamatan Tempuran. Kegiatan ini diselenggarakan selama 3 bulan, dari mulai Agustus hingga Oktober 2018.

Teknik pengumpulan data dilakukan dengan mengumpulkan sejumlah dokumen yang relevan dan penyebaran kuesioner untuk melihat indikator tingkat pengetahuan, sikap dan tindakan (kognisi, afeksi dan psikomotorik) para peserta. Indikator tersebut diukur berdasarkan pada skor pengetahuan, sikap dan tindakan dengan penggunaan kuesioner sebelum dan setelah sosialisasi. Pernyataan dalam kuesioner dikategorikan menjadi empat skala, yaitu sangat tidak setuju (STS), tidak setuju (TS), setuju (S), dan sangat setuju (SS).

Analisis data dilakukan terhadap data kualitatif dan data kuantitatif. Analisis terhadap data kualitatif digunakan untuk menganalisis data-data hasil wawancara, observasi lapangan, dan focus group discussion, sedangkan analisis terhadap data kuantitatif dilakukan untuk menganalisis data hasil pengisian kuesioner yang telah dilakukan oleh para peserta pada saat sebelum dan setelah sosialisasi.

\section{HASIL DAN PEMBAHASAN}

Kegiatan PPM ini diselenggarakan di Kecamatan Tempuran Kabupaten Karawang, dengan locus kegiatan di Desa Pancakarya dan SMAN 1 Tempuran. Kecamatan Tempuran merupakan salah satu kecamatan yang berlokasi di Kabupaten Karawang dengan 8.849 Ha, dengan jumlah penduduk 65.245 Orang di tahun 2016, dan 14 Desa.

\section{Gambar 1}

Peta Kabupaten Karawang (kiri) dan Kecamatan Tempuran (kanan)

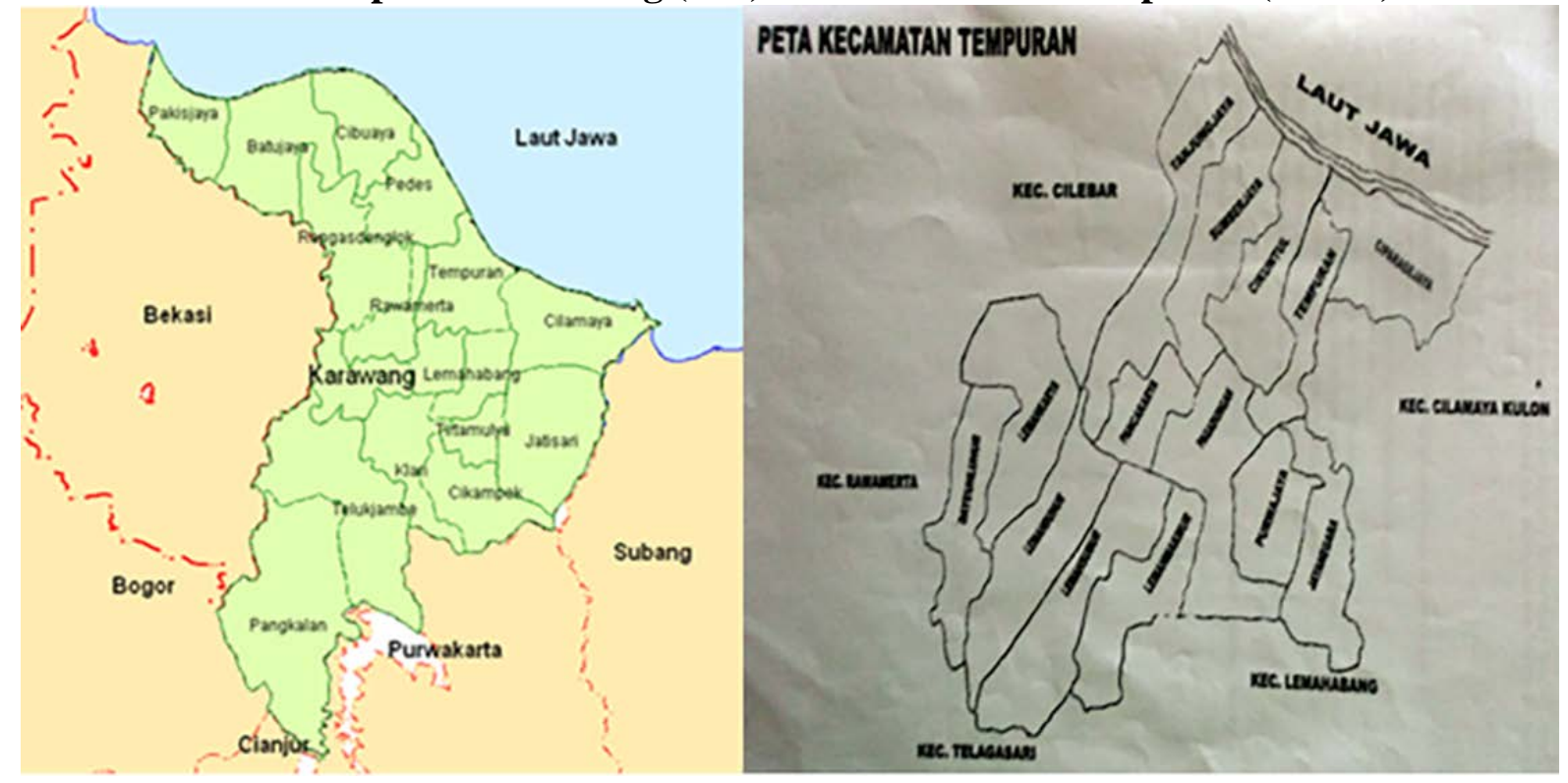

Sumber: Maps dan Olahan Peneliti, 2018 
Jumlah peserta dari PPM ini yaitu 30 siswa yang berada pada kelas 12. Kegiatan ini berfokus pada sosialisasi pencegahan radikalisasi melalui pengembangan demokrasi islamik. Kegiatan ini dilakukan melalui dua rangkaian, diantaranya sosialisasi kegiatan dan pendampingan dalam perumusan gagasan melalui metode CBR. Sebelum pelaksanaan sosialisasi, para peserta diminta untuk mengisi kuesioner yang telah disiapkan.

Kegiatan ini terbagi menjadi dua bentuk, yaitu FGD dan penyampaian materi melalui sosialisasi kegiatan. Sebelum melaksanakan sosialisasi kegiatan, terlebih dahulu kami melakukan pembagian kuesioner terhadap sejumlah siswa Sekolah Menengah Atas (SMA) di Kecamatan Tempuran untuk mengetahui sejauhmana tingkat pemahaman dan kecenderungan peserta terhadap pemikiran, sikap dan tindakan radikalisme dan radikalisasi keagamaan. Hasil data yang didapat dari kuesioner menjadi suatu pijakan untuk melaksanakan kegiatan sosialisasi pencegahan radikalisasi di kalangan siswa sekolah menengah atas di Kecamatan Tempuran. Peneliti menyusun beberapa item yang menjadi kriteria penilaian sikap dan perilaku keagamaan seseorang yang terpengaruhi oleh paham radikalisasi, yaitu suatu sikap dan perilaku yang kurang memberikan dukungan terhadap toleransi antarumat beragama, pluralitas, dan mendukung pada upaya kekerasan dalam menerapkan pemahaman keislamannya. Paham radikalisasi dalam tulisan ini juga sebagai suatu sikap dan perilaku yang mengatasnamakan Islam untuk melakukan suatu perubahan yang mendasar yang dianggap sebagai suatu sistem yang lebih baik dengan cara kekerasan atau pemaksaan kehendak. Berikut ini disajikan hasil pengolahan data kuesioner.

Tabel 1

Pemahaman Responden terhadap Isu atau Peristiwa Tertentu

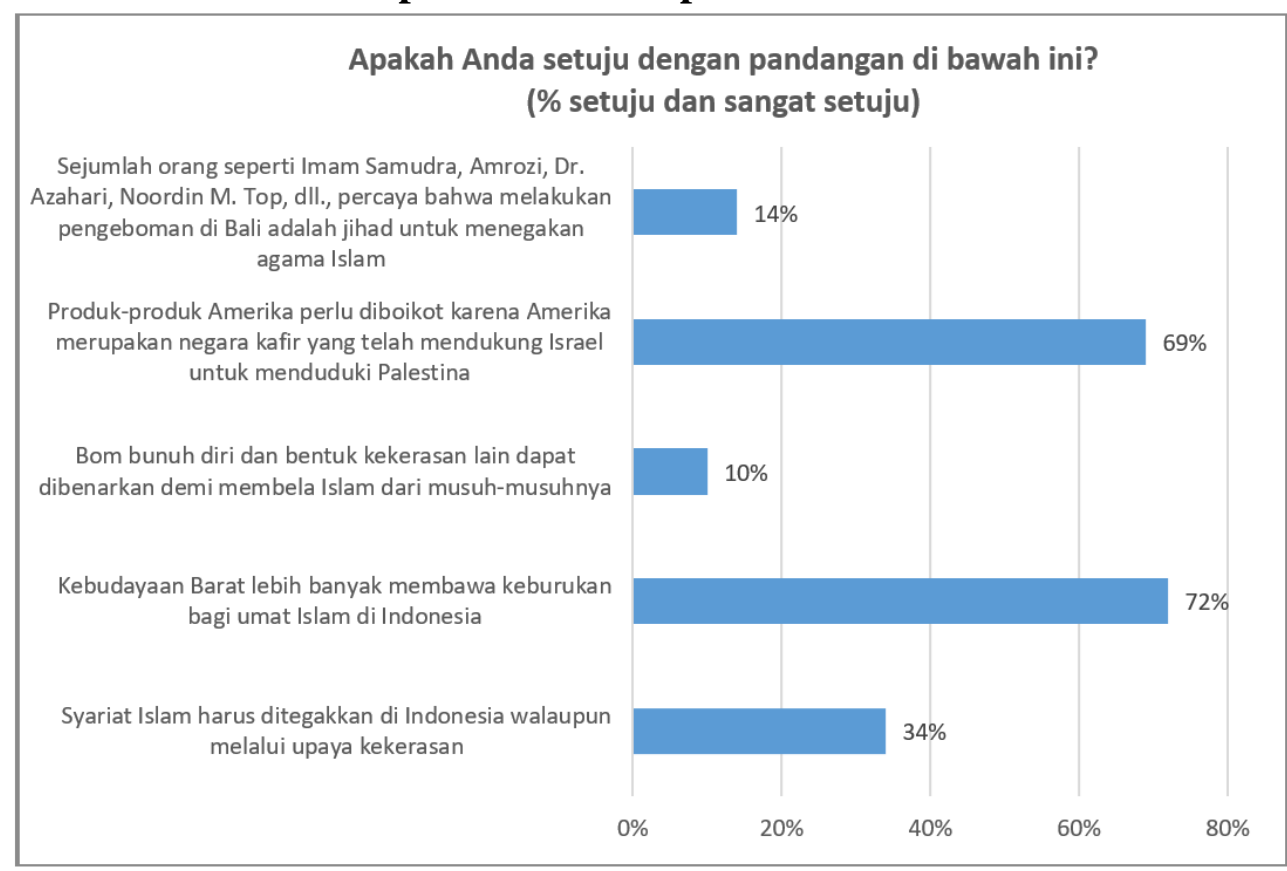

Sumber: Diolah Peneliti, 2018 
Tabel di atas merupakan hasil tanggapan responden terkait pemahaman atau pandangan mereka terhadap isu atau fenomena tertentu yang dikaitkan dengan pemahaman mereka dalam beragama. Berdasarkan tabel di atas, tampak bahwa terdapat pemahaman radikal dalam memandang jihad, dimana responden menilai bahwa pengeboman terhadap sejumlah fasilitas umum yang dilakukan oleh tokoh-tokoh terorisme merupakan jihad untuk menegakkan agama Islam. Meskipun tampak kecil, yaitu 14\% dari responden yang setuju / sangat setuju terhadap tindakan tersebut, hal ini merupakan potensi ancaman serius bagi keberlangsungan hidup berbangsa dan bernegara. Pada aspek lainnya, sebesar 69\% responden menunjukkan sisi radikalisasinya dengan memandang bahwa perlunya tindakan pembalasan (retaliation) terhadap Amerika Serikat yang telah mendukung Israel dalam menduduki Palestina. Hal ini menunjukkan sisi pembelaan terhadap umat Islam yang dipandang telah ditindas di Palestina dengan meminta pertanggungjawaban terhadap Amerika Serikat yang mendukung dan menjadi sekutu bagi Israel. Sejalan dengan tanggapan responden tersebut, pada hasil tanggapan yang serupa, sebesar 55\% responden membenci Amerika Serikat karena telah melakukan penyerangan terhadap Afganistan dan Irak yang ditafsirkan merupakan bentuk penyerangan terhadap umat Islam secara keseluruhan.

Pada tabel di atas juga, paham radikal terlihat dari responden dengan persentase sebesar 72\% yang memandang bahwa kebudayaan Barat lebih banyak membawa keburukan bagi umat Islam di Indonesia. Dalam hal ini, pandangan negatif responden terhadap kebudayaan Barat menjadi cerminan sikap dan perilaku responden sehingga berpotensi pada penolakan segala bentuk produk budaya Barat. Terkait dengan penilaian responden terhadap syariat Islam, fenomena radikalisasi keagamaan terlihat dari penilaian responden sebesar 34\% yang memandang bahwa penegakkan syariat Islam wajib ditegakkan meskipun dengan cara kekerasan. Persentase ini dapat dipandang cukup besar dan berpotensi bagi peningkatan sikap intoleransi dan ancaman keamanan bagi kehidupan berbangsa dan bernegara. 
Tabel 2

Sikap Responden dalam Beragama

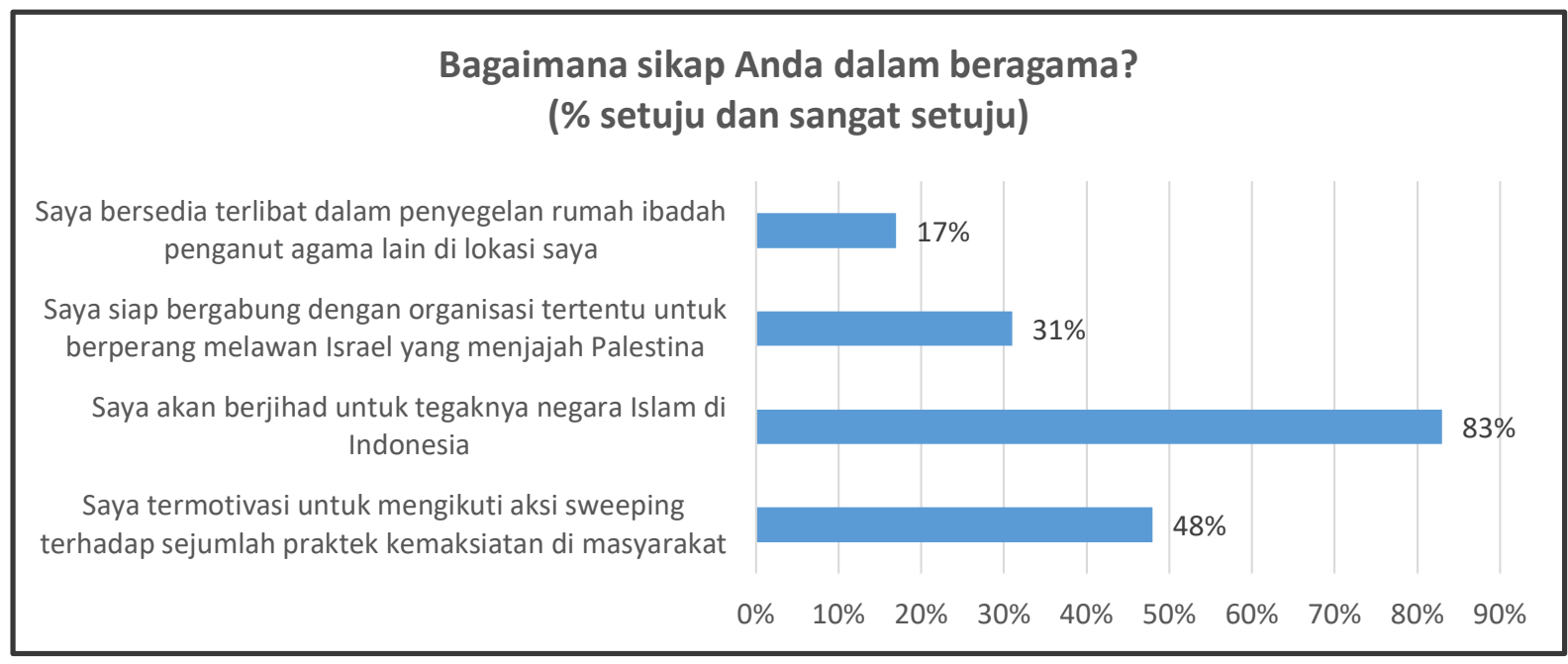

Sumber: Diolah Peneliti, 2018

Tabel di atas merupakan hasil tanggapan responden terkait sikap mereka dalam merespon isu atau fenomena yang berkembang di masyarakat yang dikaitkan dengan hasil pemahaman mereka dalam beragama. Berdasarkan tabel di atas, nampak bahwa sebanyak 17\% responden menunjukkan sikap radikalisasinya dengan bersedia terlibat dalam penyegelan rumah ibadah penganut agama lain di lokasi mereka berada. Hal ini meskipun terbilang kecil secara prosentase, namun berpotensi menimbulkan perpecahan dan anarkisme dalam masyarakat jika sikap tersebut diwujudkan dalam perilaku responden. Sejalan dengan sikap radikalisasi tersebut, sebanyak 48\% responden juga termotivasi untuk ikut serta dalam aksi sweeping terhadap sejumlah praktek kemaksiatan yang ada di masyarakat. Sikap radikalisasi keagamaan yang demikian jelas dapat menimbulkan perpecahan dan anarkisme, dimana bahwa yang berwenang dalam bertindak demi menjaga keamanan dan ketertiban adalah aparat keamanan, bukan masyarakat sebagai eksekutor dari penyimpangan sosial yang terjadi, namun masyarakat bertugas melakukan pengawasan yang bila terjadi pelanggaran terhadap norma atau aturan yang berlaku maka aparat keamanan lah yang semestinya berwenang melakukan penindakan.

Sikap radikalisasi responden juga tercermin dari jawaban mereka dalam merespon jihad dan metode melawan ketidakadilan. Berdasarkan tabel di atas, dapat kita lihat bahwa mayoritas responden, yaitu sejumlah 83\% menyatakan siap untuk berjihad demi menegakkan negara Islam di Indonesia. Bila dihadapkan pada sistem politik negara Indonesia yang berdasar pada Pancasila, sikap demikian jelas bertentangan dengan dasar dan ideologi negara sehingga berpotensi menimbulkan konflik vertikal maupun horisontal. Metode yang digunakan dalam 
merepon fenomena ketidakadilan terhadap umat Islam, ditunjukkan oleh jawaban responden sebesar 31\% yang mengambil sikap untuk bergabung dengan organisasi tertentu dalam berperang melawan Israel yang menjajah Palestina. Sikap ini tentu menjadi potensi ancaman yang nyata di tengah-tengah berkembangnya organisasi-organisasi radikal bahkan yang berafiliasi pada gerakan terorisme transnasional di Indonesia. Terbukti dengan sejumlah pengeboman terhadap fasilitas publik di Indonesia dimana pelakunya adalah jaringan terorisme transnasional.

Berdasarkan pada hasil pengolahan data kuesioner di atas, maka peneliti berupaya untuk mengenalkan radikal, radikalisme dan radikalisasi yang berkaitan dengan pemahaman, sikap dan perilaku dalam beragama. Hal ini perlu dilakukan mengingat hasil pengolahan data menunjukkan bahwa tingkat radikalisasi siswa di Kecamatan Tempuran Kabupaten Karawang perlu disikapi secara preventif agar tidak sampai membawa pada perpecahan dalam masyarakat dan mengancam toleransi dalam kehidupan beragama. Sikap inklusif dalam beragama pun diperlukan sebagai bagian dari keterbukaan masyarakat dalam merespon gejala sosial yang terjadi sesuai dengan pemahaman keagamaan yang benar. Atas dasar hal tersebut, kami melakukan beberapa kegiatan dalam upaya mencegah radikalisasi keagamaan, berikut ini akan dijelaskan beberapa kegiatan yang dimaksud.

1. Focus Group Discussion (FGD) mengenai Radikalisasi Keagamaan

Kegiatan ini FGD ini dilaksanakan pada hari Rabu, 7 November 2018 bertempat di SMAN 1 Tempuran Kabupaten Karawang. Peserta dari kegiatan ini yaitu perwakilan dari perangkat desa Pancakarya, tokoh masyarakat, tokoh pemuda dan tokoh agama. Pada awal kegiatan FGD, para peserta melakukan eksplorasi mengenai kondisi keagamaan di Kecamatan Tempuran dan permasalahan radikalisasi keagamaan yang berpotensi terjadi di masyarakat. Para peserta aktif untuk menyampaikan pendapatnya dan memberikan masukan terkait pencegahan radikalisasi keagamaan. Beberapa poin penting dari hasil FGD diantaranya:

a. Radikalisasi keagamaan terjadi karena dangkalnya pemahaman keagamaan di kalangan masyarakat;

b. Potensi radikalisasi juga disebabkan oleh kondisi sosial dan ekonomi masyarakat yang terperangkap dalam kemiskinan dan kurangnya tingkat pendidikan sehingga berpotensi pada meningkatnya rasa frustrasi dan antipati terhadap pemerintah dan kondisi yang ada; 
c. Faktor berkembangnya secara massif media sosial yang menyebabkan praktek radikalisasi mudah tumbuh dan terinternalisasi dalam masyarakat;

d. Perlunya peningkatan kepedulian dan peran kontrol dari masyarakat untuk mengawasi kondisi sekitarnya agar keamanan dan ketertiban dapat terjaga;

e. Faktor pendidikan agama yang benar yang diajarkan oleh orang tua dan guru agama menjadi hal yang utama agar generasi muda memiliki filter dalam menerima informasi keagamaan yang massif terjadi;

f. Perlu dibentuknya pemahaman demokrasi islamik dimana islam mengajarkan toleransi, anti kekerasan dalam mencapai tujuan, masyarakat pluralitas sebagai bagian dari sunnatullah yang perlu dijaga keberagamannya, penghormatan terhadap hak asasi manusia, dan sebagainya;

g. Perlunya revitalisasi bentuk dan praktek demokrasi lokal di Kecamatan Tempuran sebagai bagian dari local wisdom masyarakat yang dapat mencegah berkembangnya paham radikalisasi, seperti musyawarah warga, kerja bakti, syukuran keagamaan, peringatan hari besar nasional dan keagamaan, bahu membahu dalam menjaga keamanan lingkungan, menengok warga yang terkena musibah, kegiatan tahlilan dan sebagainya. Kebiasaan-kebiasaan tersebut dapat menghindari seseorang dari sikap individualistis dan eksklusivisme dalam beragama juga sebagai bentuk penyaluran aspirasi warga.

2. Sosialisasi Pengembangan Demokrasi Islamik

Berdasarkan data lapangan yang terkumpul dan hasil FGD, kami merumuskan substansi materi sosialisasi untuk selanjutnya melaksanakan sosialisasi pencegahan radikalisasi, khususnya terhadap siswa sekolah menengah atas di Kecamatan Tempuran dengan jumlah 30 peserta yang terdiri dari 13 siswa perempuan dan 16 siswa laki-laki dari kelas 12 . Peserta sosialisasi ini terdiri dari perwakilan siswa SMA dan yang sederajat yang ada di Kecamatan Tempuran dimana mereka pula yang menjadi sasaran pembagian kuesioner PPM. Pelaksanaan sosialisasi dilaksanakan pada Rabu, 21 November 2018 pukul 09.00 s.d. 12.30 yang bertempat di ruang kelas SMAN 1 Tempuran. Tujuan dari pelaksanaan sosialisasi pencegahan radikalisasi ini yaitu untuk memberikan pengetahuan mengenai materi yang disampaikan dan mencegah penyebaran radikalisasi di kalangan pelajar. Hal ini ditujukan kepada pelajar karena mereka termasuk golongan usia yang secara psikologis masih mencari jati diri, mudah terbawa arus negatif dan memiliki jiwa yang semangat terhadap perubahan. Kerentanan psikologis di kalangan pelajar inilah yang menimbulkan kerawanan 
terhadap potensi ancaman radikalisasi dimana target objek dari penyebaran radikalisasi ini berada pada usia remaja. Materi yang disampaikan yaitu meliputi pemahaman konsep dasar mengenai radikal, radikalisme dan radikalisasi, kemudian demokrasi dan demokrasi Islamik serta dijelaskan pula mengenai upaya pencegahan radikalisasi berdasarkan pemahaman konseptual dan hasil dari eksplorasi dalam forum FGD. Antusisme peserta sosialisasi terlihat ketika mereka menyimak materi yang disampaikan dan tingkat partisipasi yang tinggi dalam forum tanya-jawab atau diskusi. Materi yang disampaikan diselingi pula dengan cuplikan video yang relevan dengan materi sosialisasi.

\section{Gambar 2}

Sosialisasi Pencegahan Radikalisasi (kiri) dan Lokasi Sosialisasi di SMAN 1 Tempuran (kanan)

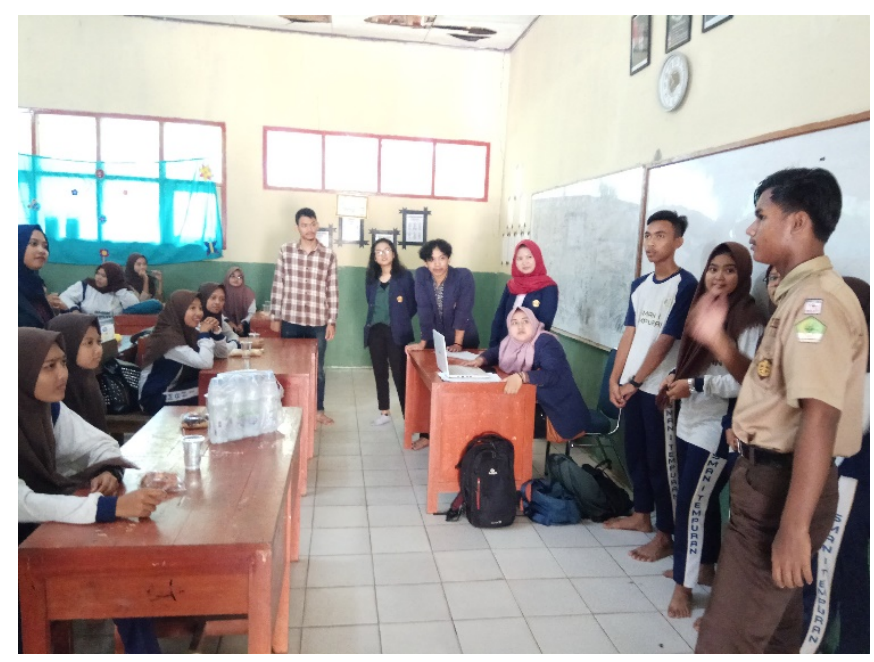

Sumber: Dokumentasi Kegiatan, 2018

Setelah kegiatan sosialisasi dilaksanakan, maka kami melakukan post test sebagai bentuk evaluasi terhadap pemahaman peserta terkait materi yang disampaikan. Soal post test merupakan kuesioner yang pernah dibagikan sebelumnya terhadap para siswa sehingga dapat digali seberapa jauh tingkat pemahaman mereka terkait radikalisasi dan bagaimana mereka merespon fenomena tersebut. Berdasarkan hasil data kuesioner, dihasilkan sebagai berikut. 
Tabel 3

Perbandingan Persentase Hasil Pre-Test dan Post-Test Pemahaman, Sikap dan Perilaku Peserta Sosialisasi

\begin{tabular}{|c|l|c|c|}
\hline \multirow{2}{*}{ No. } & \multicolumn{1}{|c|}{ Pernyataan Kuesioner } & \% Setuju/Sangat Setuju \\
\cline { 3 - 4 } 1 & \multicolumn{1}{|c|}{$\begin{array}{l}\text { Syariat Islam harus ditegakkan di Indonesia walaupun melalui upaya } \\
\text { kekerasan }\end{array}$} & $34 \%$ & $5 \%$ \\
\hline 2 & $\begin{array}{l}\text { Kebudayaan Barat lebih banyak membawa keburukan bagi umat Islam } \\
\text { di Indonesia }\end{array}$ & $72 \%$ & $0 \%$ \\
\hline 3 & $\begin{array}{l}\text { Bom bunuh diri dan bentuk kekerasan lain dapat dibenarkan demi } \\
\text { membela Islam dari musuh-musuhnya }\end{array}$ & $10 \%$ & $0 \%$ \\
\hline 4 & $\begin{array}{l}\text { Produk-produk Amerika perlu diboikot karena Amerika merupakan } \\
\text { negara kafir yang mendukung Israel untuk menduduki Palestina }\end{array}$ & $69 \%$ & $5 \%$ \\
\hline 5 & $\begin{array}{l}\text { Sejumlah orang seperti Imam Samudra, Amrozi, Dr. Azahari, dll., } \\
\text { percaya bahwa melakukan pengeboman di Bali adalah jihad untuk } \\
\text { menegakan agama Islam }\end{array}$ & $14 \%$ & $0 \%$ \\
\hline 6 & $\begin{array}{l}\text { Saya termotivasi untuk mengikuti aksi sweeping terhadap sejumlah } \\
\text { praktek kemaksiatan di masyarakat }\end{array}$ & $48 \%$ & $5 \%$ \\
\hline 7 & Saya akan berjihad untuk tegaknya negara Islam di Indonesia & $83 \%$ & $0 \%$ \\
\hline 8 & $\begin{array}{l}\text { Saya siap bergabung dengan organisasi tertentu untuk berperang } \\
\text { melawan Israel yang menjajah Palestina }\end{array}$ & $31 \%$ & $0 \%$ \\
\hline 9 & $\begin{array}{l}\text { Saya bersedia terlibat dalam penyegelan rumah ibadah penganut } \\
\text { agama lain di lokasi saya }\end{array}$ & $17 \%$ & $0 \%$ \\
\hline
\end{tabular}

Sumber: Diolah Peneliti, 2018

Setelah peserta mendapatkan pemahaman mengenai materi radikalisasi dan pencegahannya, kami melakukan evaluasi kegiatan dengan membagikan kembali kuesioner yang pernah diterima sebelum pelaksanaan sosialisasi ini dilaksanakan. Hasil dari pengolahan data kuesioner tersebut, dapat dilihat bahwa mayoritas peserta cenderung merespon ketidaksetujuan mereka terhadap sekian banyak pemahaman, sikap, dan perilaku yang mengarah pada paham radikalisasi. Terbukti dengan $0 \%$ jawaban responden yang menyatakan setuju dan sangat setuju terhadap paham radikalisasi. Sehingga dapat dikatakan bahwa rata-rata sekitar 42\% responden sebelum mengikuti pelatihan merespon setuju dan sangat setuju terhadap paham radikalisasi, disadari oleh tidak oleh responden, dan setelah mengikuti pelatihan, rata-rata sekitar $1,67 \%$ responden menyatakan setuju dan sangat setuju terhadap paham radikalisasi. Berdasarkan jawaban responden tersebut, maka dapat dikatakan bahwa kegiatan sosialisasi pencegahan radikalisasi melalui pengembangan demokrasi Islamik secara signifikan berhasil memberikan pemahaman yang benar terkait radikalisasi dan mampu mencegah penyebaran radikalisasi di kalangan siswa menengah atas di Kecamatan Tempuran Kabupaten Karawang. 
Namun demikian, pada tabel di atas nampak bahwa masih terdapat 5\% responden yang menyatakan setuju dan sangat setuju penegakkan syariat Islam di Indonesia meskipun melalui kekerasan, 5\% responden masih termotivasi untuk mengikuti aksi sweeping terhadap sejumlah praktek kemaksiatan yang terjadi di masyarakat, dan 5\% memandang perlunya memboikot produk-produk Amerika Serikat dengan alasan negara tersebut telah mendukung Israel dalam menduduki Palestina. Hal ini merupakan tantangan bagi kita, baik aparatur pemerintah maupun masyarakat untuk ikut serta menjadi bagian dalam pencegahan paham radikalisasi di Masyarakat. Pencegahan radikalisasi dengan memberikan pemahaman yang benar tentang konsep tersebut, dikaitkan dengan penyadaran akan kehidupan berbangsa dan bernegara dan pemahaman yang benar tentang keagamaan, perlu dilakukan secara berkesinambungan agar pemahaman radikalisasi di masyarakat dapat ditanggulangi hingga ke akar-akarnya.

\section{SIMPULAN}

Pelaksanaan pemberdayaan masyarakat melalui pengabdian pada masyarakat dalam kegiatan ini mampu meningkatkan pemahaman masyarakat mengenai paham radikalisasi dan upaya pencegahannya melalui kegiatan FGD dan sosialisasi pencegahan radikalisasi sehingga berimplikasi positif bagi pengamalan nilai-nilai kehidupan berbangsa dan bernegara dan pengamalan keagamaan yang benar yang mampu membawa keharmonisan dalam bermasyarakat. Kegiatan ini perlu dilakukan secara berkesinambungan mengingat penyebaran paham radikalisasi secara massif dapat tumbuh dan berkembang di era digitalisasi saat ini.

\section{DAFTAR PUSTAKA}

Afrianty, D. (2012). Islamic education and youth extremism in Indonesia. Journal of Policing, Intelligence and Counter Terrorism, 7(2), 134-146. https://doi.org/10.1080/18335330.2012.719095

Banks, S., \& Manners, P. (2012). Community-based participatory research A guide to ethical principles and practice, (November), 1-16.

Baylis, J. (2008). The Globalization of world Politics:An Introduction to International relation. New York: Oxford University Press.

Cahill, R. (2012). Notes on Radicalism. Illawarra Unity - Journal of the Illawarra Branch of the Australian, 11(1), 67-75. Retrieved from http://ro.uow.edu.au/unity/vol11/iss1/5\%0AResearch

Fealy, G. (2004). ISLAMIC RADICALISM IN INDONESIA: The Faltering Revival?, 104- 
121. Retrieved from http://www.jstor.org/stable/27913255

Golose, P. R. (2008). Seputar Kejahatan Hacking: Teori dan Studi Kasus. Jakarta: Yayasan Pengembangan Kajian Kepolisian Indonesia.

Gunaratna, R. (2002). Inside Al Qaeda: Global Network of Terror. Columbia University Press. Heiduk, F. (2012). Between a Rock and a Hard Place : Radical Islam in Post-Suharto Indonesia Between a Rock and a Hard Place : Radical Islam in Post-Suharto Indonesia. International Journal of Conflict and Violence, 6(1), 26-40. https://doi.org/10.4119/UNIBI/ijcv.191

Jati, W. R. (2013). RADICALISM IN THE PERSPECTIVE OF ISLAMIC-POPULISM: Trajectory of Political Islam in Indonesia. Journal of Indonesian Islam, 7(2), 268. https://doi.org/10.15642/JIIS.2013.7.2.268-287

Jawa Barat Kantong Radikalisme Tertinggi. (2011). Retrieved from http://www.pikiranrakyat.com/nasional/2011/10/05/160872/jawa-barat-kantong-radikalisme-tertinggi

Koehler, D. (2014). The radical online: Individual radicalization processes and the role of the Internet. Journal for Deradicalization, 0(1), 116-134. Retrieved from http://journals.sfu.ca/jd/index.php/jd/article/view/8\%5Cnhttp://journals.sfu.ca/jd/index.p hp/jd/article/download/8/8

Lestari, S. (2016). Anak-anak muda Indonesia makin radikal? Retrieved September 3, 2018, from

https://www.bbc.com/indonesia/berita_indonesia/2016/02/160218_indonesia_radikalism e_anak_muda

Lim, M. (2005). Islamic Radicalism and Anti-Americanism in Indonesia: The Role of the Internet. Policy Studies (Vol. 18). Retrieved from www.eastwestcenterwashington.org/publications

Lindsey, T. (2011). Australia and the Real Battle for Indonesian Islam. Retrieved September 6, 2018, from https://asialink.unimelb.edu.au/asialink-dialogues-and-appliedresearch/commentary-and-analysis/australia-and-the-real-battle-for-indonesian-islam

Umam, S. (2006). Radical Muslims in Indonesia: the Case of Ja'Far Umar Thalib and the Laskar Jihad. Explorations in Southeast Asian Studies, 6(1), 1-26. Retrieved from https://scholarspace.manoa.hawaii.edu/bitstream/10125/2255/1/Exp6n1-1 Umam.pdf

Van Bruinessen, M. (2002). Genealogioes of Islamic radicalism in post-Soeharto Indonesia. South East Asia Research, 10(2), 117-154. https://doi.org/10.5367/000000002101297035

Widyaningsih, R., Sumiyem, S., \& Kuntarto, K. (2017). The Potential of Religious Radicalism Movement in Banyumas. Walisongo: Jurnal Penelitian Sosial Keagamaan, 25(1), 203. https://doi.org/10.21580/ws.25.1.1807 